\title{
Settlement of Quail Primordial Germ Cells in Chicken Gonads
}

\author{
Tamao ONO, Ryohei YOKOI*, Seishi MAEDA ${ }^{1 * *}$, \\ Takao NISHIDA ${ }^{2}$ and Hirohiko AOYAMA ${ }^{3}$ \\ Faculty of Agriculture, Shinshu University, Minamiminowa-mura, \\ Nagano-ken 399-4598 \\ ' Faculty of Agriculture, The University of Tokyo, Bunkyo-ku, \\ Tokyo 113-0033 \\ ${ }^{2}$ College of Bioresource Sciences, Nihon University, Fujisawa-shi 252-0813 \\ ${ }^{3}$ JT Biohistory Research Hall, Takatsuki-shi 569-1125
}

(Received February 16, 1998)

\begin{abstract}
We transfused circulating primordial germ cells (PGCs) of quail embryos into chick embryos. To distinguish between quail and chick PGCs, we evaluated three monoclonal antibodies (mAbs), QCR 1, QB2 and 2C 9. QCR 1 and QB 2 were quail-specific $\mathrm{mAbs}$ and $2 \mathrm{C} 9$ was a chick-specific $\mathrm{mAb}$, showing development-specific expression. Chick embryos transfused with quail PGCs were observed at stage 29 of Hamburger and Hamilton's developmental standard. Transferred quail PGCs settled in the gonads and constituted $14.2 \%$ of total PGCs in the gonad. A transfused male hatchling contained two populations of spermatogonia, derived from exogenous quail and endogenous chick PGCs.
\end{abstract}

Anim. Sci. Technol. (Jpn.) 69 (6) : 546-555, 1998

Key words : Gonad, Monoclonal antibody, Primordial germ cells

Primordial germ cells (PGCs) are the first identifiable precursor cells for the gametes. Avian PGCs show a unique migration pathway during early development ${ }^{9)}$. They arise from the epiblast ${ }^{3)}$ and migrate to the hypoblast of the area pellucida, i.e., the germinal crescent, at stage $4^{5}$. From the time that the blood vessels form at stage 10 , PGCs from the germinal crescent enter the circulatory system, and by stages 20-24 they have migrated into the gonadal primordium where they rapidly proliferate to form germ cells ${ }^{4,14,27)}$. These features of PGCs' migration facilitate their isolation and transfer ${ }^{29)}$.

A number of attempts have been made to produce germline chimeras and donor-derived offspring by the transfer of PGCs in chickens $^{13,23,26)}$ and quail ${ }^{17,28)}$. This procedure will serve as a powerful tool for producing transgenic birds for genetic improvement and the production of useful products, and for preserving the foundation stocks of poultry ${ }^{23)}$. Furthermore, it will be applied to maintain a variety of poultry lines which are endangered under natural conditions ${ }^{23)}$. Interspecific transfers of PGCs have been attempted from turkeys to chickens ${ }^{20)}$, chickens to quail ${ }^{29)}$ and quail to chickens ${ }^{14,16)}$. The transferred PGCs migrated into gonadal tissues of the host animal, but there was no evidence that the

\footnotetext{
* Present address : Toxicology Laboratories, Kissei Pharmaceutical Co. Ltd., Hotakamachi, Nagano-ken $399-8305$

** Present address : Hyogo College of Medicine, Nishinomiya-shi 663-8131
} 
donor-derived PGCs differentiated into functional gametes thereafter. If their PGCs became functional, endangered species could be rescued by transferring their PGCs into the embryos of a more prolific species.

In order to investigate directly the transferred quail PGCs in the chicken, germ cell markers are required that can distinguish PGCs of quail and chicken origin. In this study, we evaluated monoclonal antibodies (mAbs) QCR 1, QB 2 and $2 \mathrm{C} 9$ as markers for PGCs. QCR 1 and QB2 were raised against optic nerves of day 13 quail embryos ${ }^{1)}$, QCR 1 recognized PGCs of day 8 quail embryos but not chick embryos ${ }^{16)}$. $2 \mathrm{C} 9$ was raised against gonads of day 6 chick embryos, and recognized PGCs of chick embryos ${ }^{10)}$. We first examined the stage-specificity of immunoreactivities of these mAbs to germ cells of quail and chickens. Next, quail embryonic blood containing PGCs was transfused into chick embryos. The transferred quail and endogenous chick PGCs which settled in the gonad were immunohistochemically obscrved on day 6 of embryonic development using QCR 1 and 2 C9. The germ cells of germline chimeric hatchling were also immunohistochemically examined using QB 2.

\section{Materials and Methods}

\section{Animals}

Fertilized eggs of wild-type plumage Japanese quail (Coturnix japonica) and White Leghorn chickens (Gallus domesticus) maintained in our laboratory were collected daily and kept at $12^{\circ} \mathrm{C}$ for not more than 3 days. The eggs were then incubated in an egg incubator at $37.5^{\circ} \mathrm{C}$ and $70 \%$ relative humidity with tilting to a 90 degree angle at $30 \mathrm{~min}$ intervals. Gonadal tissues taken from day 6-16 embryos, hatchlings and adults were used for the evaluation of mAbs (see below).

\section{Evaluation of monoclonal antibodies}

To determine the immunoreactivities of QCR 1, QB 2 and 2 C 9 against the germ cells in the gonadal tissues of the embryos, hatchlings and adults of quail and chickens, the specimens were fixed in Rossman's fluid, embedded in paraffin and cut at $6 \mu \mathrm{m}$ thickness. The sections were then processed for immunohistochemistry. For 2C9 labeling, the sections were treated with $0.3 \%$ hydrogen peroxide/ methanol for $30 \mathrm{~min} ; 1 \%$ bovine serum albumen (BSA, fraction $\mathrm{V}$ )/phosphate buffered saline (PBS, $10 \mathrm{mM}$ sodium phosphate buffer and $140 \mathrm{mM}$ sodium chloride, $\mathrm{pH} 7.2$ ) for $30 \mathrm{~min} ; 0.01 \% 2 \mathrm{C} 9 / \mathrm{PBS}$ for $60 \mathrm{~min} ; 2 \%$ biotinylated anti-mouse $\operatorname{IgG}(\mathrm{H}+\mathrm{L})$ rabbit serum/ PBS for $30 \mathrm{~min} ; 0.05 \%$ streptavidin-peroxidase complex (SABC)/PBS for $15 \mathrm{~min}$; and substrate mixture consisting of $0.83 \mathrm{mM} 3,3$ diaminobenzidine tetrahydrochloride (DAB), $4.6 \mathrm{mM}$ sodium azide, $0.02 \%$ hydrogen peroxide and $50 \mathrm{mM}$ Tris- $\mathrm{HCl}(\mathrm{pH} \mathrm{7.6)}$ for $5 \mathrm{~min}$. The procedures for QCR 1 and $\mathrm{QB} 2$ labeling were similar to that for $2 \mathrm{C} 9$, except that undiluted QCR 1 or QB 2 was used for the primary antibody treatment, and $10 \%$ normal rabbit serum/PBS was used instead of $1 \%$ BSA.

\section{Transfer of quail PGCs to chick embryos}

The micropipettes used for blood collection from donors and injection into recipients were made from siliconized glass capillary tubes $\left(\mathrm{G}^{-}\right.$ 1, Narishige, Tokyo) drawn out with a micropipette puller ( $\mathrm{PB}-7$, Narishige), and the tips were beveled with a pipette grinder (EG-4, Narishige) at 20 degrees to an outer diameter of $80-100 \mu \mathrm{m}$. Quail embryos at stages 13-15 (about $45 \mathrm{hr}$ of incubation) and chick embryos at stages 14-16 (about $53 \mathrm{hr}$ of incubation) were used as donors and recipients, respectively. At these stages, most PGCs circulate in the bloodstream ${ }^{14,22)}$. The shell of recipient embryo was cracked and the embryo with egg yolk and albumen was transferred to a $60-\mathrm{m} l$ plastic cup. To reduce the number of endogenous PGCs and to prevent high blood pressure after the transfusion, $2-6 \mu l$ of blood was removed from the marginal vein (sinus terminalis) of the recipient embryo using 
suction tubing with a mouth-piece (2-40-000, Drummond, Broomall, PA). The perforation in the recipient's vein was sealed with fine protein foam produced from $10 \%$ foetal calf serum in Leibovitz's L-15 medium. For the transfusion, the foam was pre-loaded into the micropipette, $1-2 \mu l$ of blood was taken from the donor embryo and transfused into the recipient embryo, and perforation was sealed with the foam ${ }^{29}$. Normal and blood-removed chick embryos were also cultured to estimate the population of PGCs at stage 29 .

\section{Embryo culture}

The transfused embryos were cultured in vitro in surrogate hens' egg shells ${ }^{19}$ until stage 29 or hatching. Briefly, the embryos were transferred into the bed shells prepared from the sharp end halves of small-sized hen's eggs. The bed shells were sealed with cling films (Saran Wrap, Asahi Chemical Co. Ltd., Tokyo), with thin albumen of hen's egg as an adhesive. The embryos were then cultured at $37.5^{\circ} \mathrm{C}$ and $70 \%$ relative humidity with tilting to a 30 degree angle at $30 \mathrm{~min}$ intervals.

Table 1. Immunoreactivities of QCR 1, QB 2 and $2 \mathrm{C} 9$ to germ cells of quail and chickens

\begin{tabular}{|c|c|c|c|c|c|c|c|c|c|c|c|c|c|c|c|c|}
\hline \multirow{2}{*}{$\begin{array}{l}\text { Anti- } \\
\text { body }\end{array}$} & \multirow[t]{2}{*}{ Animal } & \multirow[t]{2}{*}{$\operatorname{Sex}$} & \multicolumn{12}{|c|}{ Days of incubation } & \multirow{2}{*}{$\begin{array}{l}\text { Hatch } \\
\text { ling }\end{array}$} & \multirow[t]{2}{*}{ Adult } \\
\hline & & & 5 & 6 & 7 & 8 & 9 & 10 & 11 & 12 & 13 & 14 & 15 & 16 & & \\
\hline \multirow{3}{*}{ QCR 1} & quail & male & + & + & + & + & + & + & + & + & + & \pm & \pm & \pm & - & - \\
\hline & quail & female & + & + & + & + & + & \pm & \pm & \pm & - & - & - & - & - & ND \\
\hline & chicken & both & - & - & - & - & - & - & - & - & - & - & - & - & - & ND \\
\hline \multirow{3}{*}{ QB2 } & quail & male & + & + & + & + & + & + & + & + & + & + & + & + & + & - \\
\hline & quail & female & + & + & + & + & + & \pm & \pm & \pm & - & - & - & - & - & ND \\
\hline & chicken & both & - & - & - & - & - & - & - & - & - & - & - & - & - & $\mathrm{ND}$ \\
\hline \multirow{3}{*}{$2 \mathrm{C} 9$} & chicken & male & + & + & + & + & \pm & \pm & \pm & \pm & - & - & - & - & - & - \\
\hline & chicken & female & + & + & \pm & - & - & - & - & - & - & - & - & - & - & ND \\
\hline & quail & both & - & - & - & - & - & - & - & - & - & - & - & - & - & ND \\
\hline
\end{tabular}

+ , All germ cells are positive; \pm , Positive and negative germ cells are mixed; - , All germ cells are negative ; ND, Not determined.

Table 2. Population of PGCs in left and right gonads of normal and bloodremoved chick embryos at stage 29

\begin{tabular}{lccc}
\hline \multirow{2}{*}{ Types of embryo } & \multicolumn{3}{c}{ Number of PGCs in } \\
\cline { 2 - 4 } & Left gonad & Right gonad & Total \\
\hline Normal $(\mathrm{n}=7)$ & $407 \pm 21^{1}$ & $156 \pm 9$ & $562 \pm 25$ \\
& $(72.3 \pm 1.2 \%)^{2}$ & $(27.8 \pm 1.2 \%)$ & \\
Blood removed ${ }^{3}(\mathrm{n}=9)$ & $316 \pm 17^{* *}$ & $93 \pm 12^{* *}$ & $409 \pm 15^{* * *}$ \\
& $(72.2 \pm 2.8 \%)$ & $(22.8 \pm 2.8 \%)$ & \\
\hline
\end{tabular}

Embedded gonads were cut transversely at $6 \mu \mathrm{m}$ thickness and the PGCs in 10 sections (every fourth serial section) in the middle region of the gonad were counted. ${ }^{1}$ Mean $\pm S E .{ }^{2}$ Number in parenthesis represents the proportion of the PGCs (mean $\pm S E$ ) in each lobe of the gonad of embryo. ${ }^{3}$ The $3.0-6.0 \mu l$ of blood was removed at stages 14-16. Values with asterisks in the blood-removed embryos are significantly different from the values of the normal embryos at $\mathrm{P}<$ $0.01{ }^{(* *)}$ and $\mathrm{P}<0.001\left(^{* * *}\right)$. 


\section{Identification and counting of donor and recipient germ cells}

Quail and chick PGCs in the transfused chick embryos were identified with double-labeling by QCR 1 and $2 \mathrm{C} 9$ at stage 29. Gonadal tissues taken from the transfused chick embryos were fixed in Rossman's fluid, embedded in paraffin and serially sectioned transversely at $6 \mu \mathrm{m}$ thickness. They were first treated with the 2C 9-SABC-DAB system. The remaining antibody in the tissues was removed with $0.1 \mathrm{M}$ glycine- $\mathrm{HCl}$ buffer $(\mathrm{pH} 2.2$ ) for $2 \mathrm{hr}$. The sections were then treated with $10 \%$ normal rabbit serum/PBS for $30 \mathrm{~min}$, undiluted QCR 1 for 30 min, $2 \%$ biotinylated antimouse $\operatorname{IgG}(\mathrm{H}+\mathrm{L})$ rabbit serum/PBS for $30 \mathrm{~min}$, $\mathrm{SABC} / \mathrm{PBS}$ for $15 \mathrm{~min}$ and substrate mixture consisting of $1.1 \mathrm{mM} 4$-chloro-1-naphthol, $2 \%$

Table 3. Stages of donor and recipient embryos at transfusion, volumes of blood removed and transfused, and survival to stage 29

\begin{tabular}{cccccc}
\hline \hline $\begin{array}{l}\text { l. D. \# of } \\
\text { recipient }\end{array}$ & \multicolumn{2}{c}{ Stage at transfusion } & \multicolumn{2}{c}{ Volume of blood $(\mu l)$} & \multirow{2}{*}{$\begin{array}{c}\text { Dead or alive } \\
\text { at stage 29 }\end{array}$} \\
\cline { 2 - 5 } & Donor & Recipient & Removed & Transfused & \\
\hline 1 & 13 & 15 & 2.0 & 2.0 & Alive \\
2 & 13 & 15 & 3.5 & 2.0 & Alive \\
3 & 13 & 15 & 4.0 & 2.0 & Dead \\
4 & 13 & 16 & 3.5 & 1.0 & Alive \\
5 & 14 & 14 & 3.0 & 1.5 & Dead \\
6 & 14 & 15 & 2.0 & 1.5 & Dead \\
7 & 14 & 16 & 4.0 & 1.0 & Dead \\
8 & 14 & 16 & 6.0 & 2.0 & Dead \\
9 & 15 & 15 & 3.0 & 1.5 & Alive \\
10 & 15 & 15 & 4.0 & 1.0 & Alive \\
\hline
\end{tabular}

Table 4. Population of exogenous and endogenous PGCs in left and right gonads of embryos at stage 29

\begin{tabular}{lccc}
\hline \multirow{2}{*}{ Types of PGCs } & \multicolumn{3}{c}{ Number of PGCs in } \\
\cline { 2 - 4 } & Left gonad & Right gonad & Both gonads \\
\hline Endogenous $^{1}$ & $278 \pm 25^{2}$ & $67 \pm 7$ & $344 \pm 29$ \\
Exogenous & $(80.6 \pm 1.2 \%)^{3}$ & $(19.4 \pm 1.2 \%)$ & \\
& $55 \pm 13$ & $2 \pm 1$ & $57 \pm 14$ \\
Both & $(95.9 \pm 1.5 \%)$ & $(4.1 \pm 1.5 \%)$ & \\
& $332 \pm 27$ & $69 \pm 7$ & $401 \pm 31$ \\
& $16.5 \pm 3.7 \%$ & $\underline{2.8 \pm 1.4 \%}$ & $14.2 \pm 3.2 \%$ \\
\hline
\end{tabular}

Embedded gonads were cut transversely at $6 \mu \mathrm{m}$ thickness and the PGCs in 10 sections (every fourth serial section) in the middle region of the gonad were counted. ${ }^{1}$ The $2.0-4.0 \mu l$ of blood was removed at stages $14-16 .{ }^{2}$ Mean $\pm \mathrm{SE}$. ${ }^{3}$ Number in parenthesis represents the proportion of the PGCs (mean $\pm S E$ ) to the endogenous or exogenous PGCs, respectively. " Underlined number represents the proportion of exogenous PGCs (mean $\pm S E$ ) in left, right and both gonads, respectively. Populations of exogenous PGCs in left, right and both gonads are significantly different from the respective values of the ednogenous PGCs, and the values in the right gonads are significantly different from the respective values in the left lobe $(P<0.01)$. 
ONO, YOKOI, MAEDA, NISHIDA and AOYAMA
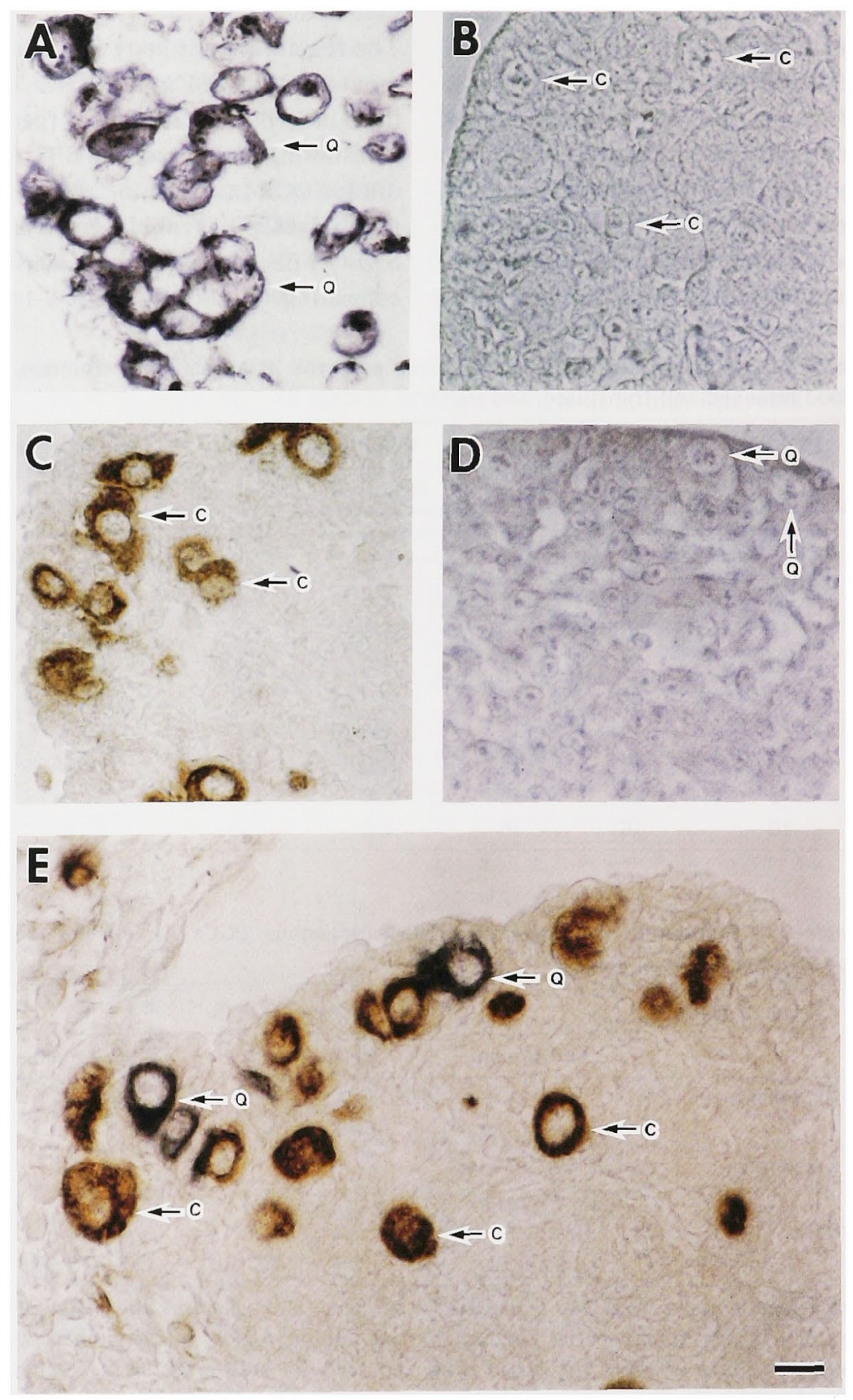

Fig. 1. Immunohistochemistry of embryonic gonadal tissues of stage 29 chick, quail and chimeric chick transfused with quail PGCs. A, quail embryo treated with QCR $1-S A B C-4 C N$; B, chick embryo treated with $\mathrm{QCR} 1-\mathrm{SABC}-4 \mathrm{CN}$; C, chick embryo treated with $2 \mathrm{C} 9-\mathrm{SABC}-$ $\mathrm{DAB}$; quail embryo treated with $2 \mathrm{C} 9-\mathrm{SABC}-\mathrm{DAB}$; chick embryo transfused with quail PGCs, treated with 2C9-SABC-DAB and QCR 1-SABC-4CN. Q, quail PGCs; C, chick PGCs. Bar indicates $10 \mu \mathrm{m}$. 


\section{Quail PGCs in Chickens}
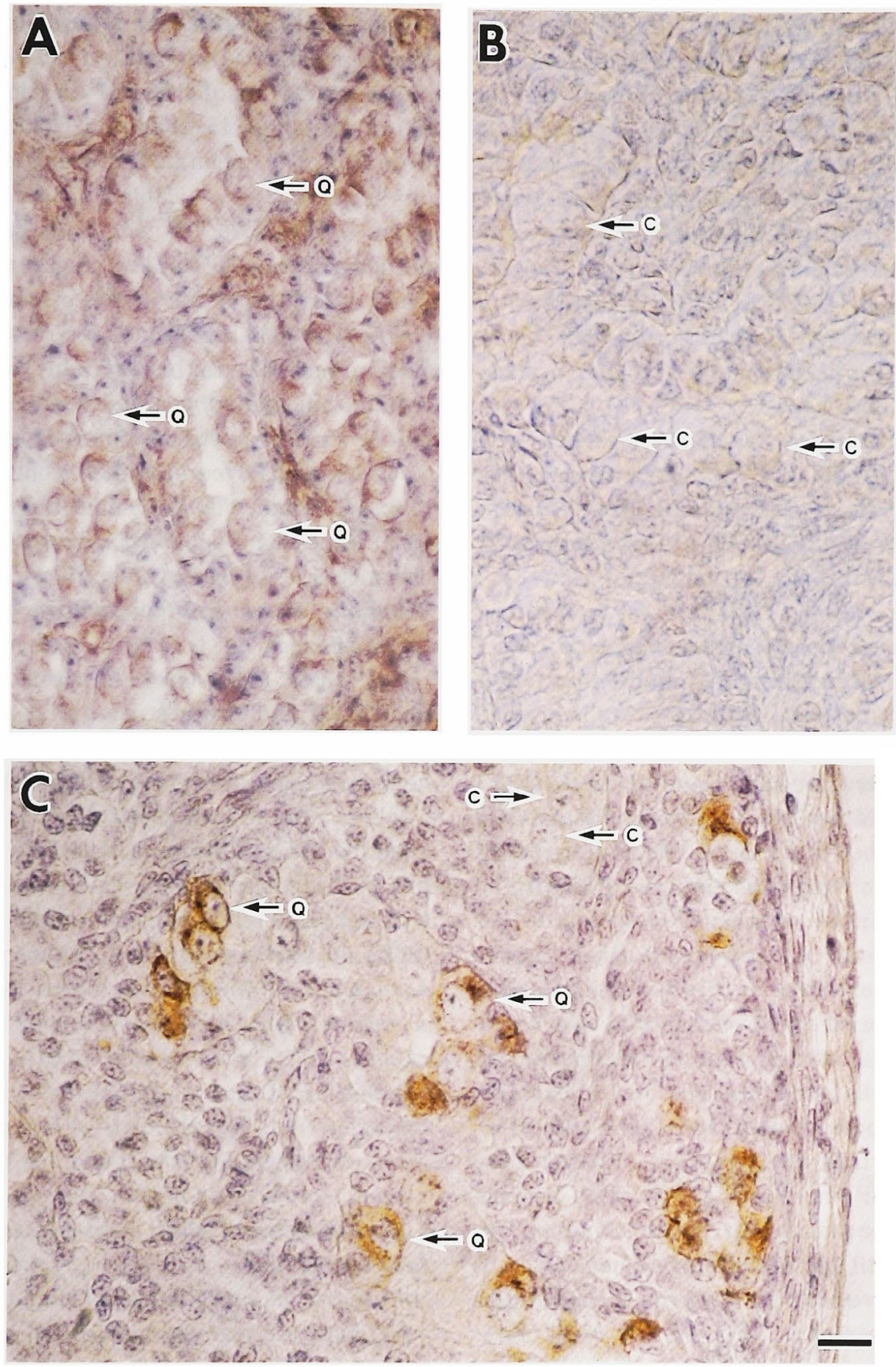

Fig. 2. Testicular tissues of newly hatched quail (A), chick (B) and chimeric chick transfused with quail PGCs, immunohistochemically stained with QB 2-SABC-DAB. Note that the two populations of spermatogonia, positively and negatively stained, are co-localized in (C). Q, quail PGCs ; C, chick PGCs. Bar indicates $10 \mu \mathrm{m}$. 
ethanol and $50 \mathrm{mM}$ Tris- $\mathrm{HCl}(\mathrm{pH} 7.6)$ for $10 \mathrm{~min}$.

The population of PGCs was indexed by counting immunohistochemically stained PGCs observed in 10 sections (every fourth serial section) in the middle region of the gonad. Normal, blood-removed, and transfused chick embryos were examined at stage 29 but the sex of embryos was not determined. Concentration of PGCs in the bloodstream of the stage 15 quail and chick embryos was estimated by a haemocytometer under a phase contrast microscope.

Gonadal tissues taken from the newly hatched male quail, chick and transfused chick were processed for immunohistochemistry using QB2 with the SABC-DAB system.

\section{Results}

\section{Immunoreactivities of mAbs to germ cells}

Table 1 summarizes the immunoreactivities of QCR 1, QB 2 and $2 \mathrm{C} 9$ to germ cells of quail and chickens as a function of development. During embryonic stages and at hatch, QCR 1 and QB2 did not label chicken cells and 2C9 did not label quail cells. Regarding QCR 1 reactivity to male quail embryos, it labeled all germ cells in the gonadal tissues until day 13 . During days $14-16$ positive and negative germ cells were observed in the tissues, and after hatch no positive cells were found. To female quail, it was positive until day 9 , positive and negative cells were observed during days $10^{-}$ 12 , and no positive cells were found thereafter. For QB 2 to male quail embryos, it was positive during embryonic stages and at hatch but negative to the adult. To female quail, it was positive until day 9 , positive and negative cells were observed during days $10-12$, and it was negative thereafter. For $2 \mathrm{C} 9$ to male chickens, it was positive until day 8 , positive and negative cells were observed during days $9-12$, and it was negative thereafter. To female chickens it was positive during days $5-6$, positive and negative cells were observed at day 7 , and it was negative thereafter.

\section{Population of PGCs in embryonic gonadal tissues}

Concentrations of PGCs in the bloodstream $(\mu l)$ of the stage 15 quail and chick embryos were 60.0 \pm 17.0 (mean $\pm S E, n=10$ ) and $32.1 \pm 9.0$ $(n=7)$, respectively. Table 2 shows the population of PGCs in left and right gonads of normal and blood-removed chick embryos at stage 29. The PGCs were immunohistochemically visualized and those in 10 sections (every fourth serial section) in the middle region of the gonad were indexed as the population. In both types of embryos, over $70 \%$ of PGCs were observed in the left gonad. Three to $6 \mu l$ of blood could be removed at stages 14 16 , and the blood-removed embryos exhibited about $30 \%$ less PGCs at stage 29.

Double immunohistochemistry of trans-

\section{fused embryos}

Ten chick embryos were transfused with quail PGCs, and 5 of these were alive at stage 29 (Table 3). Transfused PGCs had settled in the gonads of all the surviving embryos (Fig. 1 and Table 4). As shown in Fig. 1, QCR 1 did not label the PGCs in the gonads of chick embryos, but labeled those of quail embryos. The specific labeling of $2 \mathrm{C} 9$ was the reverse of that of QCR 1. Exogenous quail PGCs were stained dark blue and endogenous chick PGCs were stained brown (Fig. 1 E). The population of exogenous PGCs was about $14 \%$ of the total. Most of the exogenous PGCs were observed in the left gonads, but the distribution pattern of the endogenous PGCs was similar to that of normal embryos (Table 2).

\section{Identification of quail germ cells in a trans- fused hatchling}

Forty-seven chick embryos were transfused with quail PGCs, and 6 of them were hatched. One male hatchling was sacrificed for immunohistochemistry against QB2. At this stage the germ cells of males have differentiated into spermatogonia. QB2 labeled not chick but quail hatchlings (Figs. $2 \mathrm{~A}$ and $\mathrm{B}$ ). In the transfused hatchling, two populations of 
spermatogonia, cells positive and negative for QB 2 were co-localized in the testicular tissues, indicating that the transfused quail PGCs had differentiated into spermatogonia in the chicken testis (Fig. 2C).

\section{Discussion}

All the three mAbs, QCR 1, QB 2 and 2 C9, represent direct markers that distinguish between quail and chick germ cells, although the labelings were limited to certain periods of development. In the male chick embryo, rapid cell division of PGCs takes place between days 13 and 15, and PGCs are differentiated into spermatogonia ; and in the female it begins between days 8 and 11 , and PGCs are differentiated into oogonia ${ }^{21)}$. Developmental stages of chick embryos at days 8-11 and days 13-15 are equivalent to those of quail embryos at days $7-8$ and days $10-12$, respectively ${ }^{30}$. The stages of disappearance of these epitopes in each sex seem to depend on the differentiation of the oogonia or spermatogonia.

In the chick and quail, as in most avian species, only the left ovary becomes functional ${ }^{10)}$, and the left testis develops more than the right ${ }^{21)}$. Mayer ${ }^{12)}$ reported that an asymmetry in gonadal development was also manifested by an uneven distribution of PGCs, a greater concentration being deposited in the left gonad. The PGCs were initially deposited evenly in both gonadal primordia, at least up to day $3^{12)}$, and the asymmetry began at stage 21 , when approximately $65 \%$ of the PGCs occupied the left gonad $^{22}$.

Testicular tissues taken from the transfused male hatchling contained both QB2-positive and negative spermatogonia, indicating that the transfused quail, as well as endogenous chick, PGCs had differentiated into spermatogonia in the chicken testis. At this stage neither QCR 1 nor 2C 9 labeled germ cells, and at later stages QB 2 did not label the cells. There are several other $\mathrm{mAbs}$ specific to chick PGCs, such as EMA-1 ${ }^{25)}, \mathrm{SSEA}^{-1}{ }^{7)}, \mathrm{AGC} 5, \mathrm{AGC} 7$ and
$\mathrm{AGC} 13^{8)}$, and to the quail PGCs, such as $\mathrm{QH} 1^{18)}$ however, to the best of our knowledge, all of their immunoreactivities are limited to PGCs in the embryonic stages. It will be necessary to produce species-specific antibodies for the analysis of quail and chicken gametes. Species-specific cDNA will be useful. There are cDNAs specific to the chicken W chromosome $e^{24)}$, chicken and quail W-chromosome ${ }^{15)}$, and chicken $Z$-chromosome ${ }^{6)}$, however, those specific to only the quail genome are not available.

For the production of germline chimeric chickens, 5 chicks were raised, and 1 male and 2 females reached maturity. Unfortunately, the transfused rooster died soon after maturity, so we only obtained 13 eggs from quail inseminated by this male. These eggs were in cubated and the embryos were observed at 5 days of incubation. Four eggs were fertilized ; however, these embryos were found to be dead at very early stages. In the case of the transfused hens, these were inseminated with quail semen and 265 eggs were laid; however, none of these were fertilized.

In conclusion, we evaluated mAbs, QCR 1 , QB2 and 2C 9 as markers to distinguish between quail and chick PGCs. We were able to show that transfused quail PGCs settled in the gonads of chick embryos and hatchling. However, further research will be required to obtain donor-derived offspring born from interspecific germline chimeras.

\section{Acknowledgments}

This study was supported in part by a Grant -in-Aid from the Ministry of Education, Science, Sports and Culture, Japan to T.O..

\section{References}

1) Aoyama H, Asamoto K, Nojyo $Y$, Kinutani $M$. Monoclonal antibodies specific to quail embryo tissues: Their epitopes in the developing quail embryo and their application to identification of quail cells in quail-chick chimeras. J. Histochem. Cy tochem., $40:$ 1769-1777. 1992. 
2) Clawson RC, Domm LV. Developmental changes in glycogen content of primordial germ cells in chick embryo. Proc. Soc. Expt1. Biol. Med., 112 : 533-537. 1963.

3) Eyal-Giladi H. Kochav S. From cleavage to primitive streak formation : a complementary normal table and a new look at the first stages of development of the chick. Dev. Biol, 49 : 321-337. 1976.

4) Fujimoto T, Ukeshima A, Kiyofuji R. The origin, migration and morphology of the primordial germ cells in the chick embryo. Anat. Rec., 185 : 139-154. 1976.

5) Hamburger V, Hamilton HL. A series of normal stages in the development of the chick embryo. J. Morphol., 88 : 49-92. 1951.

6) Hori $T$, Suzuki $Y$, Solovei I, Saitoh Y, Hutchison N, Ikeda JE, Macgregor H, Mizuno $\mathrm{S}$. Characterization of DNA sequences constituting the terminal heterochromatin of the chicken $Z$ chromosome. Chromosome Res., 4 : 411-426. 1996.

7) Karageniç L, Cinnamon $Y$, Ginsburg M, Petitte $\mathrm{JN}$. Origin of primordial germ cells in the prestreak chick embryo. Dev. Genet., 19 : 290-301. 1996.

8) Kingston R, Bumstead N. Monoclonal antibodies identifying chick gonadal cells. $\mathrm{Br}$. Poult. Sci., 36 : 187-195. 1995.

9) Kuwana $\mathrm{T}$. Migration of avian primordial germ cells toward the gonadal anlage. Develop. Growth Differ., $35: 237-243.1993$.

10) Maeda $S$, Ohsako S, Kurohmaru M, Hayashi $Y$, Nishida T. Analysis for the stage specific antigen of the primordial germ cells in the chick embryo. J. Vet. Med. Sci., 56: 315-320. 1994.

11) Marshall AJ. Biology and comparative physiology of birds vol. 2. Academic Press. New York. 1961.

12) Mayer DB. The migration of primordial germ cells in the chick embryo. Dev. Biol, $10: 154-$ 190. 1964.

13) Naito M, Tajima A, Yasuda Y, Kuwana, T. Production of germline chimeric chickens, with high transmission rate of donor-derived gamates, produced by transfer of primordial germ cells. Mol. Reprod. Dev., 39 : 153-161. 1994.

14) Nakamura $M$, Kuwana $T$, Miyayama $Y$, Fujimoto T. Extragonadal distribution of primordial germ cells in the early chick embryo. Anat. Rec., 222 : 90-94. 1988.

15) Ogawa A, Solovei I, Hutchison N, Saitoh $Y$, Ikeda JE, Macgregor $\mathrm{H}$, Mizuno S. Molecular characterization and cytological mapping of a non-repetitive DNA sequence region from the $\mathrm{W}$ chromosome of chicken and its use as a universal probe for sexing Carinatae birds. Chromosome Res., 5 : 93-101. 1997.

16) Ono $T$, Yokoi R, Aoyama $H$. Transfer of male and female primordial germ cells of quail into chick embryonic gonads. Exp. Anim., 45 : 347352.1996.

17) Ono $T$, Matsumoto $T$, Arisawa $Y$. Germline chimeric quail produced by transfer of primordial germ cells. Proc. 8th AAAP Anim. Sci. Congress, 2 : 48-49. 1996.

18) Pardanaud L, Buck C, Dieterlen-Lievre F, Early germ cell segregation and distribution in the quail blastodisc. Cell Diff., $22: 47-60.1987$.

19) Perry MM. A complete culture system for the chick embryo. Nature, 331 : 70-72. 1988.

20) Reynaud G. Capacites reproductricés et descendance de Poulets ayant subi un trans fert de cellules germinales primordiales durant la vie embryonnaire. Roux's Arc. Dev. Biol. $179: 85-110.1976$.

21) Romanoff AL. The avian embryo. Structural and Functional Development. Macmillan. New York. 1960

22) Singh RP, Meyer DB. Primordial germ cells in blood smears from chick embryos. Science, 156: 1503-1504. 1967.

23) Tajima A, Naito M, Yasuda $Y$, Kuwana T. Production of germ line chimera by transfer of primordial germ cells in the domestic chicken (Gallus domesticus). Theriogenology, 40:509519. 1993.

24) Tone M, Nakano $\mathrm{N}$, Takao E, Narisawa $S$, Mizuno S. Demonstration of W chromosomalspecific repetitive DNA sequences in the domestic fowl, gallus g. domesticus. Chromosome, $86: 551-569.1982$.

25) Urven LE, Erickson CA, Abbott UK, McCarrey $J R$. Analysis of germ line development in the chick embryo using an anti-mouse EC cell antibody. Development, 103 : 299-304. 1988.

26) Vick L, Luke G, Simkiss, K. Germ-line chimaeras can produce both strains of fowl with high efficiency after partial sterilization. J. Reprod. Fert., $98:$ : 637-641. 1993.

27) Watanabe $M$, Naito $M$, Sasaki E, Sakurai $M$, Kuwana T, Oishi T. Liposome-mediated DNA transfer into chicken primordial germ cells in vivo. Mol. Reprod. Dev., 38 : 268-274. 1994.

28) Wentworth BC, Tsai H, Hallett JH, Gonzales DS, Rajcic-Spasojevic G. Manipulation of 


\title{
Quail PGCs in Chickens
}

avian cells and gonadal differentiation. Poultry Sci., 68 : 999-1010. 1989.

29) Yasuda Y, Tajima A, Fujimoto T, Kuwana T. A method to obtain avian germ-line chimeras using isolated primordial germ cells. J. Reprod.
Fert., 96 : 521-528. 1992.

30) Zacchei AM. Lo sviluppo embrionale della quaglia giapponese (coturnix coturnix japonica T.e S.). Arch. Ital. Anat. Embryol., 66:36-62. 1961 .

\section{ウズラ始原生殖細胞のニワトリ生殖腺への移住}

\author{
小野珠乙 ・横井亮平 ${ }^{*} \cdot$ 前田誠司 ${ }^{1 * *} \cdot$ 西田隆雄 ${ }^{2)} \cdot$ 青山裕彦 $^{3)}$ \\ 信州大学農学部，長野県南箕輪村 399-4598 \\ 1) 東京大学農学部，東京都文京区 113-0033 \\ 2) 日本大学生物資源科学部, 藤沢市 $252-0813$ \\ ${ }^{3} \mathrm{JT}$ 生命誌研究館, 高槻市 569-1125
}

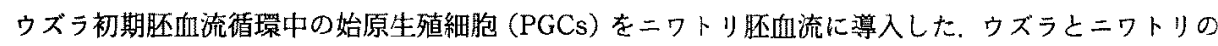
PGCs 識別するために, 3 種のモノクローナル抗体，QCR 1，QB 2, 2C9について，ニワトリおよびウ ズラ生殖細胞における免疫組織化学的染色性を調べた，QCR 1，QB2 はウズラ特異的であり，2C9は二 ワトリ特異的であった。さらに, 3 種とあ発生段階特異的染色性を示した。 ウズラ PGCsを導入したニワ トリ胚を Hamburger and Hamilton のステージ29 で調ベたところ, 生殖腺にウズラ PGCsが定住して おらり，全体の $14.2 \%$ を占めた。 ウズラPGCs 導入したニワトリ雄七ナ精巣に外来のウズラおよび内在 のニワトリの精原細胞の $2 つ の$ 集団が観察された.

日畜会報, $69(6): 546-555,1998$

*現所属: キッセイ薬品工業, 長野県穂高町 399-8305

** 現所属 : 兵莗医科大学, 西宮市 $663-8131$

日畜会報，69（6）：546-555 